\title{
BAKTERI PADA IKAN GABUS Channa striata, SEMAH Tor spp., DAN BAUNG Hemibagrus sp.: IDENTIFIKASI, VIRULENSI, DAN KERENTANAN TERHADAP BEBERAPA ANTIBIOTIK
}

\author{
Desy Sugiani", Uni Purwaningsih, Septyan Andrianto, dan Angela Mariana Lusiastuti \\ *) Balai Riset Perikanan Budidaya Air Tawar dan Penyuluhan Perikanan \\ Jl. Sempur No. 1, Bogor 16154
}

(Naskah diterima: 7 Januari 2019; Revisi final: 15 Maret 2019; Disetujui publikasi: 15 Maret 2019)

\begin{abstract}
ABSTRAK
Identifikasi mikroflora ikan air tawar adalah alat penting untuk evaluasi kualitas dan keamanan ikan untuk dipelihara dalam sistem budidaya intensif. Penelitian ini bertujuan untuk mendeteksi bakteri ikan air tawar terutama dari ikan gabus, semah, dan baung hasil tangkapan dan budidaya pada kolam. Bakteri yang terisolasi dari jaringan ginjal, hati, luka, dan otak ikan gabus (Channa striata), semah (Tor spp.), dan baung (Hemibagrus sp.) diidentifikasi dengan uji fisik dan biokimia, dan dilanjutkan dengan menggunakan API 20 E dan API 20 Strep. Uji virulensi untuk melihat kemampuan patogenisitas dari masing-masing isolat bakteri

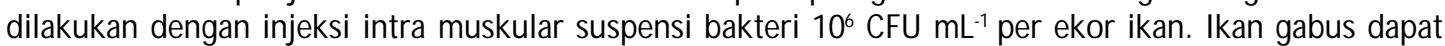
terinfeksi bakteri Pasteurella pneumotropica dan Aeromonas hydrophila, ikan semah rentan terhadap Enterococcus faecium, Pantoea spp., dan A. hydrophila, sedangkan ikan baung rentan terhadap infeksi Citrobacter freundii dan A. hydrophila. Bakteri Enterococcus faecium, Pantoea sp., dan A. hydrophila memiliki tingkat virulensi yang rendah antara 3,3\%23,4\% sedangkan C. freundii dan P. pneumotropica tidak virulen pada ikan gabus, semah, dan baung. Batas dosis atas untuk antibiotik berdasarkan petunjuk penggunaan obat untuk enrofloksasin adalah $10 \mathrm{mg} / \mathrm{L}$; eritromisin 3,75 mg/L; dan oksitetrasiklin $250 \mathrm{mg} / \mathrm{L}$. Hasil uji kerentanan dengan metode difusi zona hambat menunjukkan bahwa telah terjadi resistensi pada bakteri Pantoea spp., E. faecium, dan A. hydrophila terhadap antibiotik enrofloksasin dan eritromisin, dan resistensi pada bakteri E. faecium terhadap oksitetrasiklin.
\end{abstract}

\section{KATA KUNCl: ikan gabus; ikan semah; ikan baung; bakteri; virulensi}

ABSTRACT: Bacteria in Channa striata, Tor sp., and Hemibagrus sp.: identifications, virulence and antibiotics susceptibility. By: Desy Sugiani, Uni Purwaningsih, Septyan Andrianto, dan Angela Mariana Lusiastuti

\begin{abstract}
Identification of microflora in freshwater fish is an important tool to evaluate the health quality of fish cultured in intensive aquaculture systems. This study aimed to investigatebacteria in freshwater fish, determine their virulence and test their susceptibility to antibiotics. The freshwater fish species of interest in this study wereChanna striata spp., and Hemibagrus sp. originated from wild catch and fish farming ponds. Isolated bacteria from kidney, liver, skin wound, and brain tissue were identified using physical and biochemical tests followed by API 20 E and API 20 Strep KIT tests. Pathogenicity test of each bacterial isolate was carried out by intramuscular injection of $10_{6} \mathrm{CFU} \mathrm{mL}$ of bacterial suspension per fish. Snakehead fish (Channa striata) was susceptible to Pasteurella pneumotropica and Aeromonas hydrophila infections, Cyprinidae (Tor spp.) was susceptible to Enterococcus faecium, Pantoea spp., and A. hydrophila, while Catfish (Hemibagrus sp.) was susceptible to Citrobacter freundii and A. hydrophila infections. Bacteria $E$. faecium, Pantoea sp. and A. hydrophila have a low virulence level of 3.3\%23.4\% whereas $C$. freundii and $P$. pneumotropica were both non-virulent to snakehead, cyprinidae, and catfish. The highest recommended dosages for enrofloxacin, erythromycin, and oxytetracycline were $10 \mathrm{mg} / \mathrm{L}, 3.75 \mathrm{mg} / \mathrm{L}$, and $250 \mathrm{mg} / \mathrm{L}$, respectively. The results of antibiotics sensitivity test showed that Pantoea spp., E. faecium, and A. hydrophila bacteria were resistant to enrofloxacin and erythromycin, while $\mathrm{E}$. faecium bacteria was resistant to oxytetracycline.
\end{abstract}

KEYWORDS: Channa striata; Tor spp.; Hemibagrus sp.; bacteria; virulence

\footnotetext{
\# Korespondensi: Balai Riset Perikanan Budidaya Air Tawar dan Penyuluhan Perikanan. Jl. Sempur No. 1, Bogor 16154, Indonesia.

Tel. + 622518313200

E-mail: desysugiani@yahoo.co.id
} 


\section{PENDAHULUAN}

Penyakit yang diakibatkan oleh infeksi bakteri secara umum ditandai dengan adanya luka berwarna kemerahan, borok, pembusukan sirip, insang pucat dan nekrosis, pembengkakan rongga perut, eksopthalmia, dan melanosis. Bakteri Aeromonas hydrophila dapat menginfeksi ikan baung (Hemibagrus nemurus), menyebabkan kematian ikan dan dapat mengganggu performa pertumbuhan (Farhana et al., 2015). Ikan gabus (Channa striata) dapat terinfeksi bakteri motile aeromonad dari jenis Aeromonas hydrophila, A. caviae, dan Pseudomonas fluorescens (Courtenay \& Williams, 2004).

Hasil pemeriksaan bakteriologis dari berbagai organ (hati, ginjal, usus, dan otot bagian dalam) dan sampel air kolam ikan air tawar jenis Cyprinidae (Tor tambroides, T. duoronensis, Puntius schwanenfeldii, dan P. gonionotus) diperoleh sebanyak 16 spesies bakteri, yang terdiri atas tujuh spesies bakteri Gram negatif: Aeromonas hydrophila, Citrobacter freundii, Escherichia coli, Enterobacter aerogenes, Klebsiella sp., Pseudomonas sp., Vibrio anguillarum, dan tiga spesies bakteri Gram positif: Bacillus Sp., Listeria, dan Staphylococcus (Apun et al., 1999).

Bakteri A. hydrophila banyak ditemukan di air tawar, ikan, dan telur ikan, menyebabkan kematian tinggi dan zoonosis untuk manusia (Alkhunni et al., 2017). Kematian ikan akibat serangan penyakit infeksius dipengaruhi oleh faktor ketahanan ikan, lingkungan, dan tingkat virulensi dari patogen. Bakteri dari jenis Enterobacteriaceae memiliki potensi sebagai enteropatogen yang dapat menyebabkan wabah penyakit apabila adanya penurunan kualitas lingkungan (Apun et al., 1999). Frekuensi terjadinya bakteri yang berpotensi menjadi patogen pada sistem budidaya ikan secara terbuka akan lebih tinggi jika dibandingkan dengan budidaya ikan dalam sistem resirkulasi (Majewska, 2016).

Identifikasi mikroflora ikan air tawar yang memiliki potensi untuk menjadi patogen penyebab penyakit adalah metode penting untuk melakukan evaluasi kualitas dan keamanan ikan sebelum dipelihara dalam sistem budidaya intensif. Tujuan dari penelitian ini adalah untuk mendeteksi bakteri ikan air tawar terutama ikan gabus, semah, dan baung hasil tangkapan maupun dari hasil budidaya pada kolam. Selain itu, untuk mengetahui tingkat virulensi dari masingmasing bakteri yang terisolasi pada ketiga ikan tersebut, dan kerentanan bakteri virulen terhadap beberapa antibiotik.

\section{BAHAN DAN METODE}

\section{Ikan Uji}

Sampel untuk identifikasi bakteri pada ikan gabus (Channa striata) berasal dari hasil tangkapan pada perairan umum di daerah Parung, Depok, Indramayu, dan Yogyakarta, ikan semah (Tor spp.) berasal dari hasil pemeliharaan di kolam tanah di Cijeruk, sedangkan ikan baung (Hemibagrussp.) berasal dari hasil tangkapan pada perairan umum daerah Karawang dan Cibalagung. Ikan-ikan untuk uji virulensi diperoleh dari wilayah Jawa Barat dan diaklimatimasi selama 21 hari pada bak fiber volume $100 \mathrm{~m}^{3}$. Uji virulensi menggunakan ikan yang sehat, ikan gabus sebanyak 10 ekor/bak dengan rata-rata panjang total $7 \pm 0,8 \mathrm{~cm}$; semah $(5 \pm 0,5$ $\mathrm{cm})$; dan baung $(5 \pm 1,2 \mathrm{~cm})$.

\section{Identifikasi Bakteri}

Ikan yang digunakan untuk isolasi bakteri adalah ikan sehat dan ikan yang menunjukkan gejala sakit seperti warna tubuh pucat, terdapat luka, sirip geripis, dan gerakan renang lemah. Masing-masing lima ekor ikan sehat dan lima ekor ikan sakit digunakan untuk isolasi bakteri. Ikan-ikan tersebut dianastesi terlebih dahulu dengan larutan minyak sirih konsentrasi $1 \mathrm{~mL} /$ L air selama 15-20 menit sampai tidak ada lagi pergerakan dan respons dari ikan sebelum dilakukan pembedahan. Isolat bakteri dari jaringan ginjal, hati, luka, dan otak diambil dengan ose dan dikultur pada media Triptic Soy Agar (TSA) dan Brain Heart Infusion Agar (BHIA) kemudian diinkubasikan pada suhu $28^{\circ} \mathrm{C}$ $30^{\circ} \mathrm{C}$ selama 24 jam. Koloni yang tumbuh dipilih berdasarkan bentuk, ukuran, dan warna kemudian dikultur ulang pada media TSA/BHIA untuk selanjutnya diidentifikasi dengan uji fisik dan biokimia meliputi pewarnaan gram, motilitas, sitokrom oksidase, oksidatif fermentatif (O-F), dekarboksilase glukosa, dan $\mathrm{H}_{2} \mathrm{~S}$. Setiap koloni juga dikultur dalam media selektif dan diidentifikasi menggunakan KIT API 20 E dan API 20 Strep.

\section{Uji Virulensi Bakteri}

Uji virulensi dilakukan untuk melihat patogenisitas dari masing-masing isolat bakteri melalui injeksi secara intramuskular 0,1 mL suspensi bakteri per ekor ikan. Inokulan bakteri untuk uji virulensi ditanam pada media agar dan di panen ke dalam $10 \mathrm{~mL}$ salin steril $0,845 \%$ masing-masing isolat dilakukan pengenceran

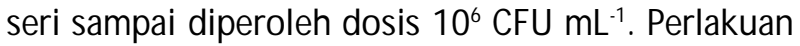
uji virulensi terhadap ikan gabus, semah, dan baung dilakukan dengan tiga kali ulangan dan setiap bak diisi 
10 ekor ikan. Masing-masing jenis ikan diinjeksi dengan isolat bakteri dari hasil uji biokimia dan identifikasi. Bakteri tersebut meliputi Pasteurella pneumotropica, Aeromonas hydrophila, Enterococcus faecium, Pantoea spp., dan Citrobacter freundii. Ikanikan tersebut dipelihara selama 14 hari dan diamati gejala klinis meliputi perubahan pola berenang, tingkah laku makan, perubahan patologi anatomi organ dalam dan luar, dan kematian ikan.

\section{Uji Kerentanan Antibiotik}

Uji sensitivitas terhadap beberapa jenis antibiotik menggunakan metode difusi zona hambat (Tendencia, 2004). Uji sensitivitas diawali dengan uji daya larut antibiotik terhadap air, untuk melihat kemampuan bahan antibiotik tersebut tersuspensi dalam pelarut air. Daya larut ini penting dilakukan karena akan memengaruhi keampuhan dari zat aktif yang terkandung dalam antibotik. Antibiotik yang diujikan adalah enrofloksasin, eritromisin, dan oksitetrasiklin. Isolat bakteri ditumbuhkan dalam media agar kemudian kertas cakram yang telah mengandung antibiotik diletakkan ditengah petri pada inokulan bakteri uji. Pengujian uji sensitivitas untuk setiap isolat bakteri dan setiap jenis antibitoik menggunakan petri terpisah. Agar tersebut diinkubasi selama 24 jam pada suhu $28^{\circ} \mathrm{C}$. Zona bening yang terbentuk diukur untuk menentukan diameter zona hambat.

\section{HASIL DAN BAHASAN}

\section{Identifikasi Bakteri}

Isolat bakteri yang diperoleh dari hasil isolasi ikan gabus, semah, dan baung berjumlah 17 isolat, ginjal (empat isolat), hati (empat isolat), luka (enam isolat), dan otak (tiga isolat), kemudian dilakukan klasifikasi berdasarkan bentuk dan warna koloni yang sama maka diperoleh hasil untuk koloni bakteri yang berbeda dari ikan gabus (Channa striata) ada dua isolat; dari ikan semah (Tor spp.) tiga isolat, dan dari ikan baung (Hemibagrus sp.) dua isolat. Setiap isolat dilakukan uji fisik, uji menggunakan media spesifik Rhimler Shotts (RS) dan media Triple Sugar Iron Agar (TSIA) diperoleh hasil empat isolat dengan karakter yang berbeda dan tiga isolat dengan karakter yang sama.

Lima isolat bakteri kemudian dilakukan uji lanjut dengan keragaman berbeda terdiri atas kelompok bakteri Gram negatif dan bakteri Gram positif, bersifat motil dan non-motil, berbentuk batang (rod) dan bulat (cocci), menunjukkan karakter spesifik berdasarkan hasil uji biokimia menggunakan KIT identifikasi bakteri API 20 E dan menggunakan KIT identifikasi bakteri API 20 Strep (Tabel 1). Hasil uji fisik dan uji biokimia teridentifikasi lima jenis spesies bakteri yaitu Pasteurella pneumotropica, Aeromonas hydrophila, Enterococcus faecium, Pantoea spp., dan Citrobacter freundii (Tabel 2).

Aeromonas hydrophila adalah patogen penyebab MAS (M otile Aeromonad Septicemia) di perairan air tawar, payau, dan laut dengan kisaran inang yang beragam. Motil Aeromonas spp. dianggap sebagai patogen oportunistik dan dapat dengan mudah ditemukan dalam perairan yang kaya dengan kandungan bahan organik. Stres dan kualitas air yang buruk menjadi peran kunci dalam kejadian kematian ikan akibat infeksi A. hydrophila (Oztürk \& Altýnok, 2014).

Bakteri Citrobacter freundii menyebabkan kematian kronis pada ikan manfish (Pherophyllum scalare) dengan gejala menunjukkan kelesuan, tumor bibir, hemoragi, dan granuloma hati (Gallani et al., 2016). Uji karakter fenotipik menggunakan Api 20 E berhasil mengidentifikasi bakteri Citrobacter freundii pada kasus kematian ikan rainbow trout (Oncorhynchus mykiss) di Serbia dengan gejala adanya gastroenteritis, inflamasi di usus, peradangan, dan nekrotik di organ internal (Svetlana et al., 2003). Bakteri C. freundii juga teridentifikasi dari kasus kematian ikan rainbow trout yang dipelihara dalam karamba di Wilayah Laut Hitam Turki (Ture \& Kutlu, 2018).

Enterobacteriaceae digunakan sebagai indikator umum kualitas lingkungan dan memiliki potensi menjadi bakteri patogen pada ikan dan lingkungan akuatik, dari 23 sampel ikan air tawar dari dua sumber air yang berbeda yaitu Sungai Driksna dan kolam di Dobele Latvia terdeteksi kontaminasi mikroflora ikan air tawar di antaranya adalah Pantoea spp. (9\%), Aeromonas spp. (5\%), dan Enterobacter spp. (1\%) (Kluga et al., 2017). Entero bacteriaceae (Pantoea agglomerans) teridentifikasi dengan API $20 \mathrm{E}$ dari organ ginjal ikan seabass dengan tingkat prevalensi 2,04\% pada ikan budidaya dan $0 \%$ pada ikan yang diambil di perairan umum Adriatik Utara selama periode satu tahun pengamatan, ada korelasi hubungan antara penyakit dan kondisi patofisiologi pada ikan liar dan budidaya (Rakovac et al., 2002).

\section{Uji Virulensi Bakteri}

Hasil uji virulensi menunjukkan bahwa bakteri Pantoea sp. mematikan ikan gabus sebanyak 20\% bakteri Enterococcus faecium mematikan ikan gabus 13,3\% dan ikan semah 3,3\% bakteri Aeromonas hydrophila mematikan ikan baung $23,4 \%$ sedangkan bakteri Citrobacter freundii dan Pasteurella pneumotropica bersifat tidak mematikan (non virulent) (Tabel 3). Semua bakteri yang terisolasi memiliki tingkat virulensi yang rendah pada ikan gabus, baung, dan semah dengan mortalitas ikan $\leq 30 \%$ pada 14 hari pasca-infeksi buatan 
Tabel 1. Karakter bakteri hasil identifikasi dengan API 20 E dan API 20 Strep

Table 1. Bacterial identification using API $20 \mathrm{E}$ and API 20 Strep

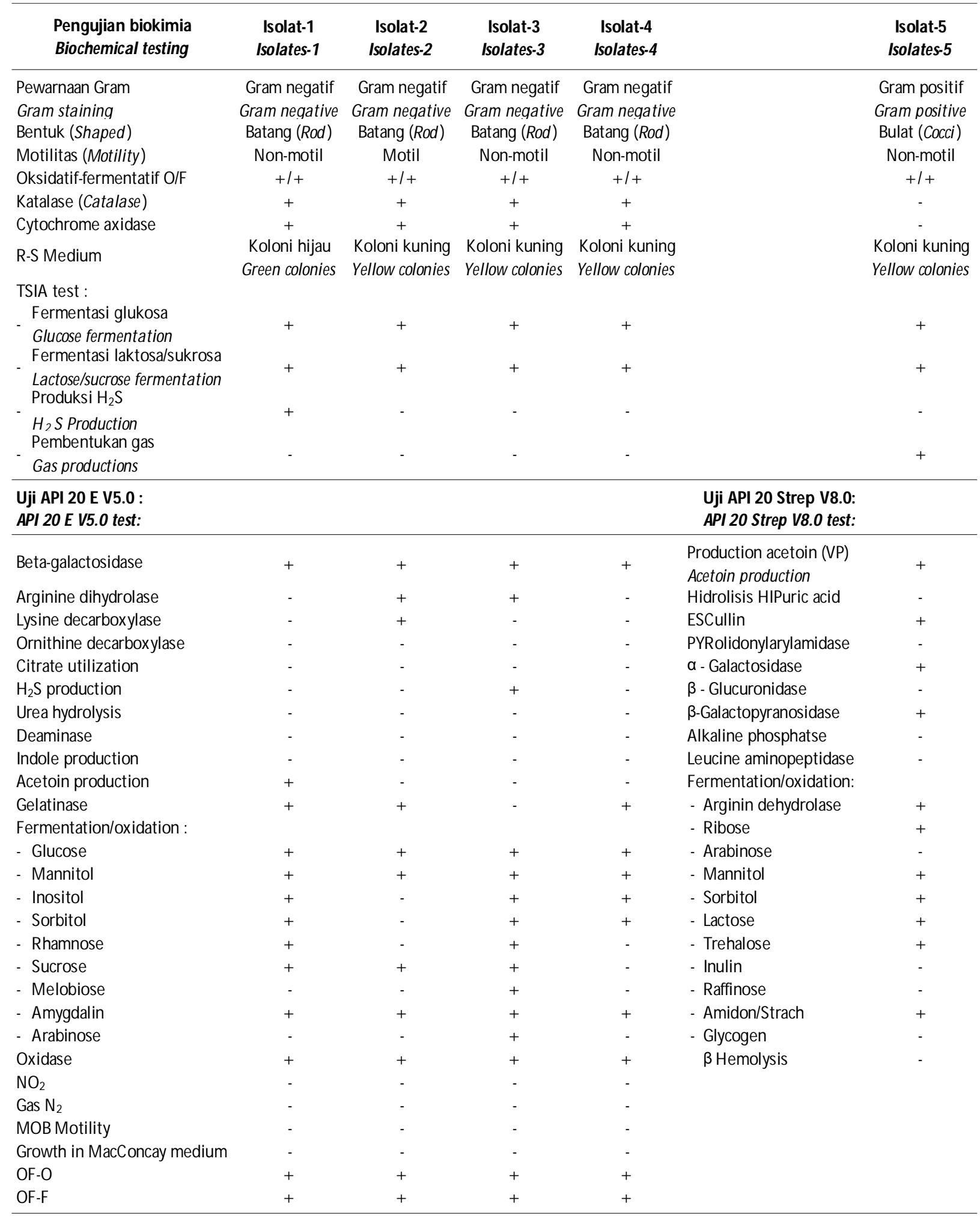

Keterangan (Note):

$\begin{array}{ll}+ & : \text { positif (positive) } \\ - & \text { : negatif (negative) } \\ \text { isolat-1 (isolates-1) } & \text { Pantoea sp. } \\ \text { isolat-2 (isolates-2) } & \text { Aeromonas hydrophila } \\ \text { isolat-3 (isolates-3) } & \text { Citrobacter freundii } \\ \text { isolat-4 (isolates-4) : Pasteurella pneumotropica } \\ \text { isolat-5 (isolates-5) }: \text { Enterococcus faecium }\end{array}$


Tabel 2. Isolat bakteri yang teridentifikasi dari ikan

Table 2. Identification of bacterial isolates from fish

\begin{tabular}{lccc}
\hline Nama ilmiah & \multicolumn{2}{c}{ Spesies ikan (Fish species) } & Bakteri \\
\cline { 2 - 3 } Scientific name & $\begin{array}{c}\text { Nama lokal } \\
\text { Local name }\end{array}$ & $\begin{array}{c}\text { Nama umum } \\
\text { Common name }\end{array}$ & Bacteria \\
\hline Channa striata & Gabus & Snakehead & $\begin{array}{c}\text { Pasteurella pneumotropica } \\
\text { Aeromonas hydrophila }\end{array}$ \\
\hline Tor spp. & $\begin{array}{c}\text { Semah, Kancra, } \\
\text { Mahseer }\end{array}$ & Cyprinidae & $\begin{array}{c}\text { Enterococcus faecium } \\
\text { Pantoea spp. } \\
\text { Aeromonas hydrophila }\end{array}$ \\
\hline Hemibagrus sp. & Baung & Catfish & $\begin{array}{c}\text { Citrobacter freundii } \\
\text { Aeromonas hydrophila }\end{array}$ \\
\hline
\end{tabular}

dengan dosis yang diinjeksikan sebanyak $10^{6} \mathrm{CFU} \mathrm{mL}^{-}$

${ }^{1}$ (Gambar 1). Walaupun ketiga bakteri ini memiliki tingkat virulensi yang rendah, akan tetapi dikhawatirkan akan menyebabkan wabah apabila terdapat cekaman stres pada ikan akibat perubahan lingkungan maupun karena pengaruh penanganan dalam sistem budidaya yang tidak mengikuti kaidah Cara Budidaya Ikan yang Baik (CBIB).
Pola kematian harian ikan gabus, semah, dan baung setelah diinfeksi bakteri Aeromonas hydrophila, Citrobacter freundii, dan Pasteurella pneumotropica menunjukkan bahwa ketiga jenis bakteri dapat mematikan pada beberapa ikan dengan masa kritis 28 hari pasca-infeksi dengan gejala klinis adanya radang dan borok pada area bekas injeksi, nafsu makan berkurang, berenang lemah, dan pada beberapa ikan

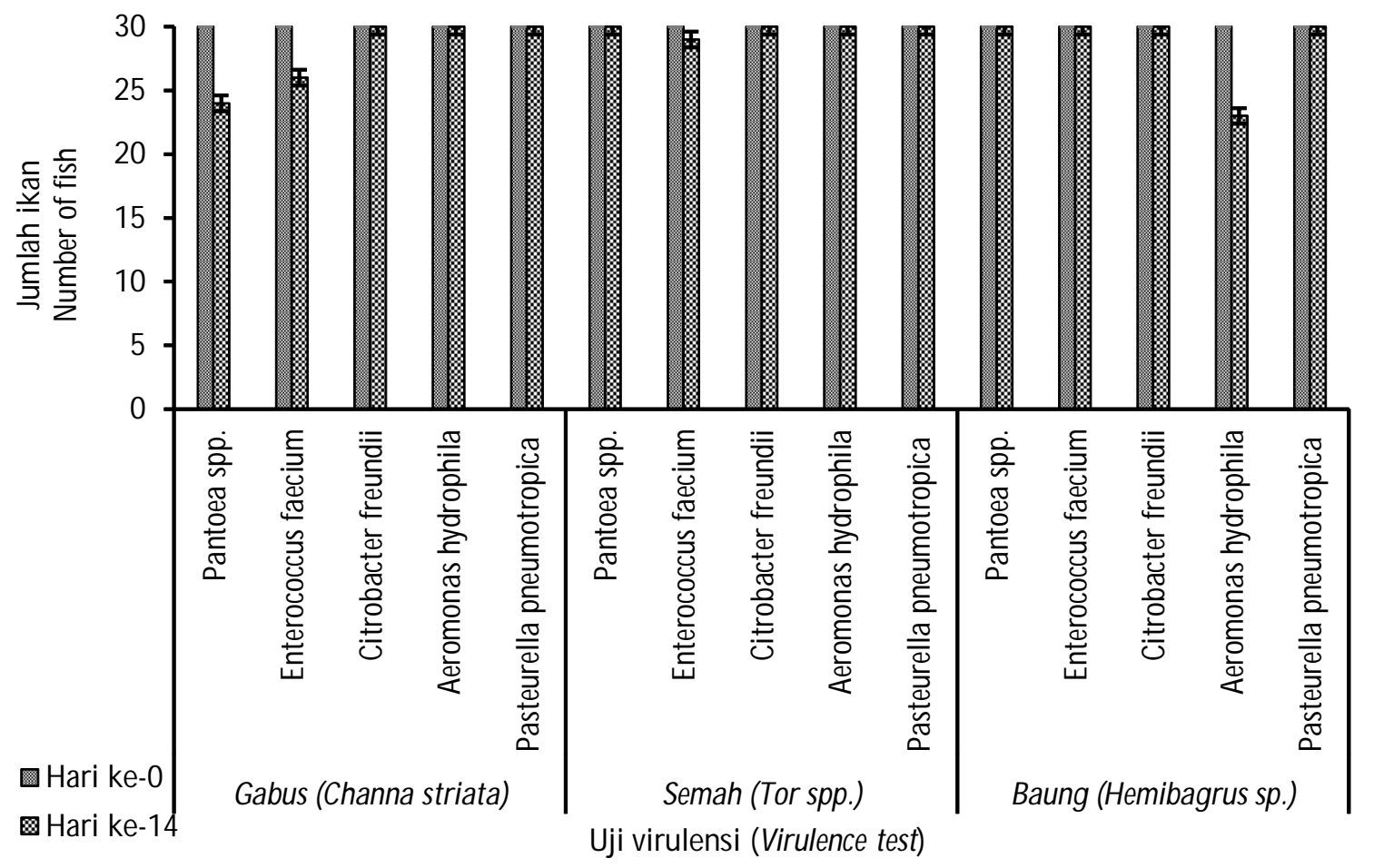

Gambar 1. Total kematian ikan gabus, semah, dan baung pada uji virulensi.

Figure 1. Total mortality of Channa striata, Tor spp., and Hemibragus sp. in virulence test. 
Tabel 3. Mortalitas ikan pasca diuji tantang dengan bakteri

Table 3. Mortality rate of fish post bacterial challenge test

\begin{tabular}{|c|c|c|c|}
\hline \multirow{2}{*}{$\begin{array}{l}\text { Uji virulensi pada ikan } \\
\text { Challenge test on fish }\end{array}$} & \multicolumn{3}{|c|}{ Mortalitas/Mortality (\%) } \\
\hline & $\begin{array}{c}\text { Gabus } \\
\text { Channa striata }\end{array}$ & $\begin{array}{l}\text { Semah } \\
\text { Tor spp. }\end{array}$ & $\begin{array}{c}\text { Baung } \\
\text { Hemibagrus sp. }\end{array}$ \\
\hline Pantoea spp. & $20 \pm 20.0$ & $0 \pm 0.0$ & $0 \pm 0.0$ \\
\hline Enterococcus faecium & $13.3 \pm 11.55$ & $3.3 \pm 5.77$ & $0 \pm 0.0$ \\
\hline Citrobacter freundii & $0 \pm 0.0$ & $0 \pm 0.0$ & $0 \pm 0.0$ \\
\hline Aeromonas hydrophila & $0 \pm 0.0$ & $0 \pm 0.0$ & $23.4 \pm 11.55$ \\
\hline Pasteurella pneumotropica & $0 \pm 0.0$ & $0 \pm 0.0$ & $0 \pm 0.0$ \\
\hline
\end{tabular}

menunjukkan gejala warna tubuh lebih gelap, namun sembilan hari pasca-infeksi ikan sudah menunjukkan gejala persembuhan di mana luka radang dan borok pada area bekas injeksi menjadi kering dan tidak terjadi kematian (Gambar 2, 3, dan 4).

Bakteri Pantoea sp., E. faecium, dan A. hydrophila bersifat virulen karena memiliki kemampuan untuk mematikan ikan gabus, semah, dan baung. Kayis et al. (2009) mengemukakan bahwa ikan rainbow trout (Oncorhynchus mykiss) dapat terinfeksi bakteri Pantoea spp., A. hydrophila, C. freundii, dan P. pneumotropica.

Baketri Aeromonas hydrophila, Citrobacter freundii, dan Pantoea sp., Enterobacter sp. dapat terdeteksi pada ikan hias Liopropoma santi (Al-Hisnawi et al., 2016). Enterococcus sp. adalah organisme komensal dan dapat menyebabkan penyakit dalam kondisi tertentu. Faktor virulensi yang bertanggung jawab di antaranya kemampuan aktivitas sitolisin, gelatinase, produksi zat agregasi (Savasan et al., 2016).

\section{Uji Kerentanan Antibiotik}

Uji kerentanan antibiotik menggunakan tiga jenis antibiotik yang memiliki nomor register di Kementerian Kelautan dan Perikanan (KKP) untuk bakteri akuatik di antaranya adalah enrofloksasin, eritromisin, dan oksitetrasiklin. Masing-masing jenis antibiotik memiliki kemampuan menghambat dan mematikan pertumbuhan bakteri target yang berbeda. Antibiotik enrofloksasin tidak dapat larut sempurna dan mudah mengendap, sedangkan eritromisin dan oksitetrasiklin dapat terlarut sempurna dalam air (Tabel 4).

Daya larut antibiotik terhadap air ini sangat penting karena aplikasi pemberian antibiotik dalam perairan dan budidaya ikan lebih banyak menggunakan metode perendaman. Efektivitas daya hambat antibiotik terhadap bakteri target akan dipengaruhi oleh kemampuan daya larut terhadap air. Hal ini dapat terlihat dari hasil uji sensitivitas enrofloksasin dengan

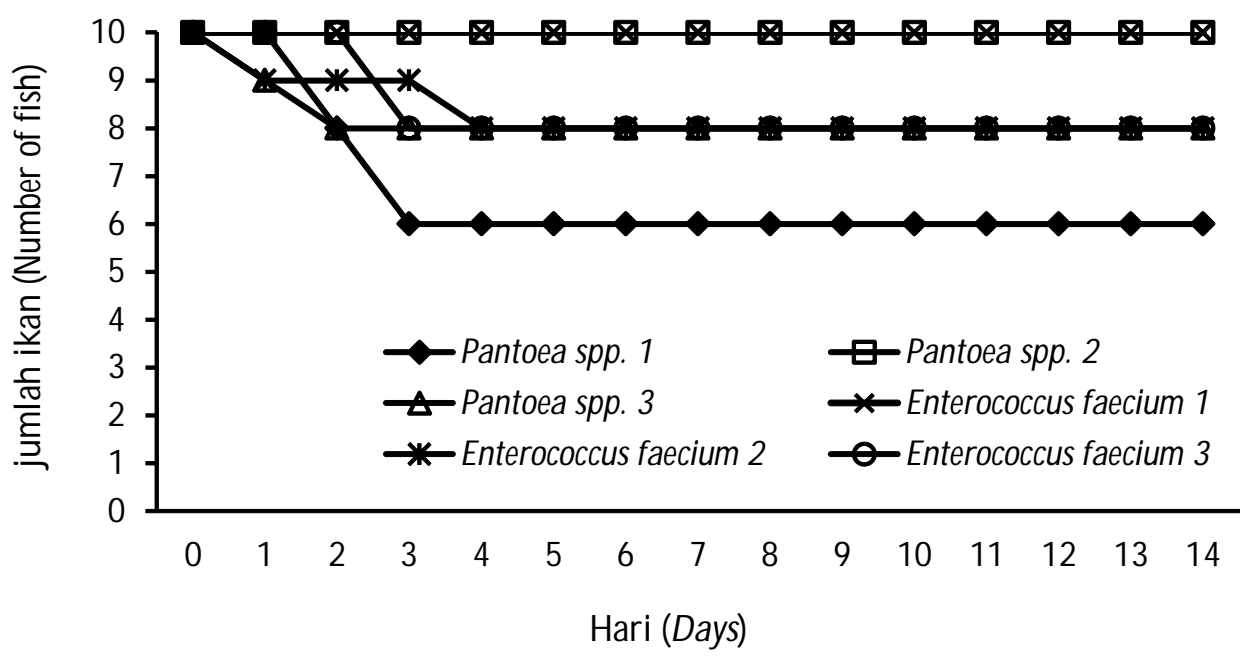

Gambar 2. Pola kematian harian ikan gabus pasca uji tantang dengan bakteri.

Figure 2. The pattern of daily mortality of Channa striata post bacterial challenge test. 


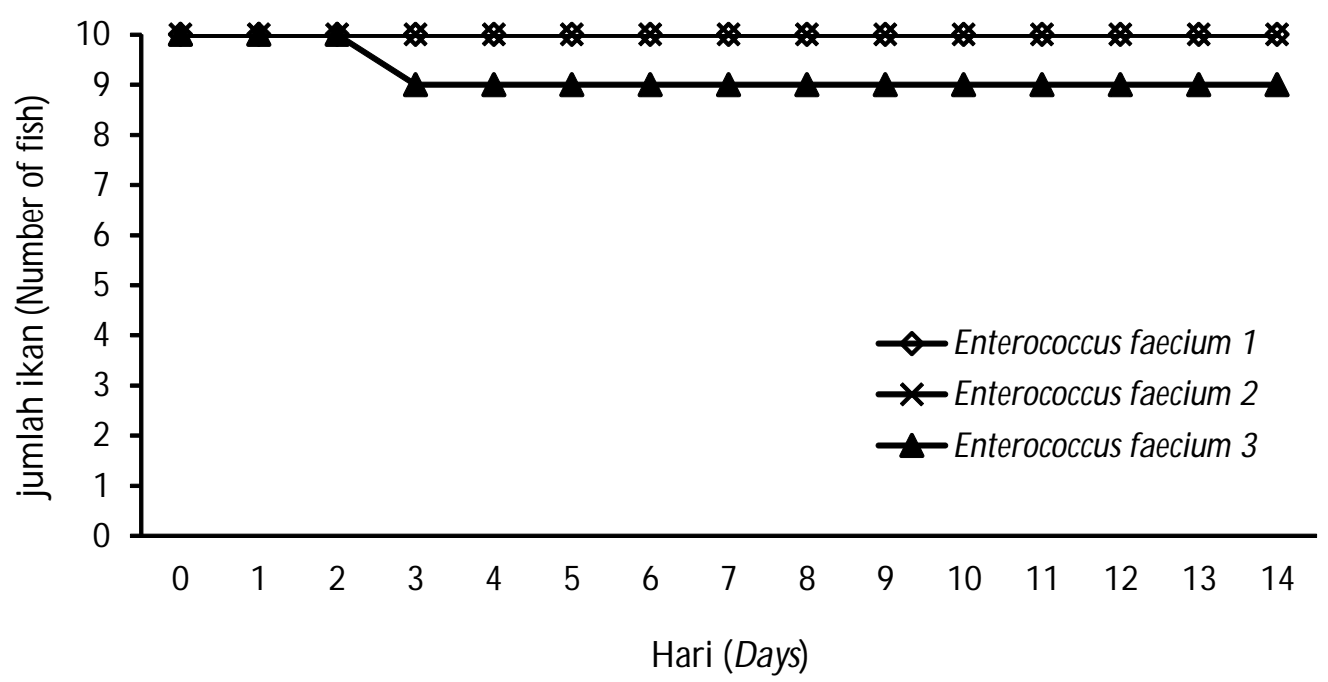

Gambar 3. Pola kematian harian ikan semah pasca uji tantang dengan bakteri.

Figure 3. The pattern of daily mortality of Hemibagrus sp. post bacterial challenge test.

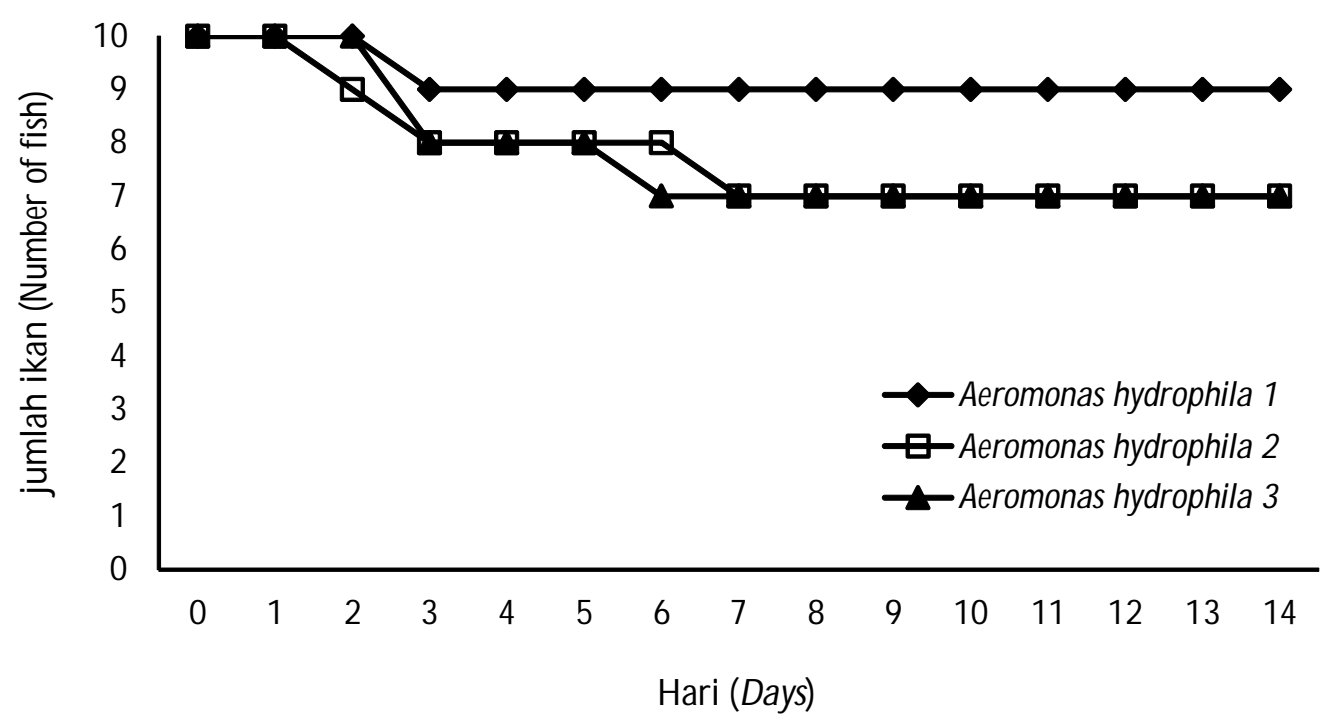

Gambar 4. Pola kematian harian ikan baung pasca uji tantang dengan bakteri.

Figure 4. The pattern of daily mortality of Tor spp. post bacterial challenge test.

dosis rendah maupun dosis tinggi keduanya memiliki nilai standar deviasi yang tinggi dan hasil uji yang tidak linier di antara gradasi dosis (Tabel 5 dan 6).

Batas dosis atas untuk antibiotik berdasarkan petunjuk pada kemasan dagang untuk enrofloksasin adalah $10 \mathrm{mg} / \mathrm{L}$; eritromisin 3,75 mg/L; dan oksitetrasiklin $250 \mathrm{mg} / \mathrm{L}$. Hasil uji menunjukkan bahwa telah terjadi resistensi pada bakteri Pantoea spp., E. faecium, dan A. hydrophila terhadap antibiotik enrofloksasin dan eritromisin, dan resistensi pada bakteri E. faecium terhadap oksitetrasiklin (Tabel 5). Enterococcus faecium memiliki tingkat resistensi yang tinggi terhadap antibiotik trimetoprim, kloramfenikol, eritromisin, oksitetrasiklin, sulfametoksazol, dan siprofloksasin (Igbinosa et al., 2016). Lingkungan akuakultur dapat menjadi reservoir strain bakteri resisten antibiotik yang mampu berkontribusi terhadap penyebaran resistensi antimikroba di lingkungan.

Hasil uji sensitivitas bakteri Pantoea sp. menunjukkan bahwa bakteri tersebut rentan terhadap enrofloksasin pada dosis tinggi $\geq 30 \mathrm{mg} / \mathrm{L}$. Pertumbuhan Pantoea sp., dapat dihambat oleh oksitetrasiklin pada dosis lebih dari $200 \mathrm{mg} / \mathrm{L}$. Bakteri Enterococcus faecium rentan terhadap enrofloksasin pada dosis tinggi $\geq 3.000 \mathrm{mg} / \mathrm{L}$, dan oksitetrasiklin 
Tabel 4. Spesifikasi antibiotik untuk bakteri akuatik dan karakter daya larut dalam air Table 4. Antibiotic specifications for aquatic bacteria and characteristics of water solubility

\begin{tabular}{|c|c|c|c|c|}
\hline $\begin{array}{c}\text { Bahan aktif } \\
\text { Active ing redients }\end{array}$ & $\begin{array}{c}\text { Anjuran dosis } \\
\text { Recommended dosage } \\
\text { (mg/L) }\end{array}$ & $\begin{array}{l}\text { Bakteri/penyakit } \\
\text { Bacteria/disease }\end{array}$ & $\begin{array}{l}\text { Daya larut } \\
\text { Solubility }\end{array}$ & $\begin{array}{l}\text { Warna larutan } \\
\text { The color of } \\
\text { the solution }\end{array}$ \\
\hline $\begin{array}{l}\text { Enrofloksasin } \\
200 \mathrm{mg}\end{array}$ & $5-10$ & $\begin{array}{c}\text { Aeromonas hydrophila, A. } \\
\text { salmonicida, Renibacterium } \\
\text { salmoninarium, Vibrio } \\
\text { harveyi }\end{array}$ & $\begin{array}{l}\text { Sulit larut dan } \\
\text { mengendap } \\
\text { Hard to dissolve and } \\
\text { solids settle }\end{array}$ & $\begin{array}{l}\text { Putih } \\
\text { White }\end{array}$ \\
\hline $\begin{array}{l}\text { Eritromisin } \\
400 \mathrm{mg}\end{array}$ & $2.5-3.75$ & $\begin{array}{l}\text { Bacterial kidney disease, } \\
\text { Streptococcosis, } \\
\text { Furunculosis }\end{array}$ & $\begin{array}{l}\text { Mudah larut dan } \\
\text { terlarut sempurna } \\
\text { Completely dissolve }\end{array}$ & $\begin{array}{l}\text { Bening } \\
\text { Clear liquids }\end{array}$ \\
\hline $\begin{array}{l}\text { Oksitetrasiklin } \\
400 \mathrm{mg}\end{array}$ & $25-250$ & $\begin{array}{c}\text { Gram posiitif dan Gram } \\
\text { negatif: } \\
\text { Positive Gram and } \\
\text { Neegative Gram: } \\
\text { Aeromonas sp., } \\
\text { Edwardsiella sp., } \\
\text { Yersinia sp. }\end{array}$ & $\begin{array}{l}\text { Mudah larut dan } \\
\text { terlarut sempurna } \\
\text { Completely dissolve }\end{array}$ & $\begin{array}{l}\text { Kuning } \\
\text { Yellow }\end{array}$ \\
\hline
\end{tabular}

Tabel 5. Hasil uji sensitivitas antibiotik dosis rendah

Table 5. The results of antimicrobial susceptibility testing using low dosage

\begin{tabular}{|c|c|c|c|c|c|c|c|}
\hline \multirow{3}{*}{$\begin{array}{l}\text { Bakteri } \\
\text { Bacteria }\end{array}$} & \multicolumn{6}{|c|}{ Zona hambat//nhibitory zone (mm) } & \multirow{3}{*}{$\begin{array}{l}\text { Klasifikasi } \\
\text { Classifications }\end{array}$} \\
\hline & \multirow{2}{*}{$\begin{array}{l}\text { Antibiotik } \\
\text { Antibiotics }\end{array}$} & \multicolumn{5}{|c|}{ Dosis (Dosage) } & \\
\hline & & 1 & 2 & 3 & 4 & 5 & \\
\hline \multirow{3}{*}{ Pantoea spp. } & Enrofloksasin & - & - & - & - & - & Resisten (Resistant) \\
\hline & Eritromisin & - & - & - & - & - & Resisten (Resistant) \\
\hline & Oksitetrasiklin & $25.0 \pm 1.0$ & $23.0 \pm 2.0$ & $11.0 \pm 2.0$ & - & - & Rentan (Susceptible) \\
\hline \multirow{3}{*}{ E. faecium } & Enrofloksasin & - & - & - & - & - & Resisten (Resistant) \\
\hline & Eritromisin & - & - & - & - & - & Resisten (Resistant) \\
\hline & Oksitetrasiklin & - & - & - & - & - & Resisten (Resistant) \\
\hline \multirow{3}{*}{ A. hydrophila } & Enrofloksasin & $17.0 \pm 2.0$ & $17.0 \pm 1.0$ & $21.3 \pm 4.5$ & $19.3 \pm 2.5$ & $16.6 \pm 0.6$ & Intermediet (Intermediates) \\
\hline & Eritromisin & $6.67 \pm 0.6$ & - & - & - & - & Resisten (Resistant ) \\
\hline & Oksitetrasiklin & $22.7 \pm 0.6$ & $21.0 \pm 1.0$ & $13.3 \pm 1.5$ & $5.3 \pm 1.5$ & - & Rentan (Susceptible) \\
\hline
\end{tabular}

Keterangan (Note):

- $\quad$ : tidak ada zona hambat (no zone of inhibition)

Dosis 1 (Dosage 1) : enrofloxacin $30 \mathrm{mg} / \mathrm{L}$; erythromycin $5 \mathrm{mg} / \mathrm{L}$; oxytetracycline $250 \mathrm{mg} / \mathrm{L}$

Dosis 2 (Dosage 2) : enrofloxacin $20 \mathrm{mg} / \mathrm{L}$; erythromycin $4 \mathrm{mg} / \mathrm{L} ; 0$ oxytetracycline $200 \mathrm{mg} / \mathrm{L}$

Dosis 3 (Dosage 3) : enrofloxacin $15 \mathrm{mg} / \mathrm{L}$; erythromycin $3 \mathrm{mg} / \mathrm{L}$; oxytetracycline $150 \mathrm{mg} / \mathrm{L}$

Dosis 4 (Dosage 4) : enrofloxacin $10 \mathrm{mg} / \mathrm{L}$; erythromycin $2 \mathrm{mg} / \mathrm{L}$; oxytetracycline $75 \mathrm{mg} / \mathrm{L}$

Dosis 5 (Dosage 5) : enrofloxacin $5 \mathrm{mg} / \mathrm{L}$; erythromycin $1 \mathrm{mg} / \mathrm{L}$; oxytetracycline $20 \mathrm{mg} / \mathrm{L}$

dosis $250 \mathrm{mg} / \mathrm{L}$. Bakteri Aeromonas hydrophila rentan terhadap enrofloksasin dosis tinggi $30 \mathrm{mg} / \mathrm{L}$, dan oksitetrasiklin dosis rendah pada $200 \mathrm{mg} / \mathrm{L}$. Bakteri Pantoea sp., E. faecium dan A. hydrophila resisten terhadap eritromisin sampai dosis $5.000 \mathrm{mg} / \mathrm{L}$ (Tabel 6).
Hasil karakterisasi resistensi antibiotik bakteri Enterococci yang diisolasi dari sedimen dan perairan air laut terhadap antibiotik eritromisin (ERY), tetrasiklin (TET), dan ampisilin (AMP) dengan metode Minimum Inhibitory Concentration (MIC) ditemukan bahwa terdapat 25 isolat Enterococcus faecium yang 
Tabel 6. Hasil uji sensitivitas antibiotik dosis tinggi

Table 6. The results of antimicrobial susceptibility testing using high dosage

\begin{tabular}{|c|c|c|c|c|c|c|}
\hline \multirow{3}{*}{$\begin{array}{l}\text { Bakteri } \\
\text { Bacteria }\end{array}$} & \multicolumn{5}{|c|}{ Zona hambat/Inhibitory zone ( $\mathrm{mm}$ ) } & \multirow{3}{*}{$\begin{array}{l}\text { Klasifikasi } \\
\text { Classifications }\end{array}$} \\
\hline & \multirow{2}{*}{$\begin{array}{l}\text { Antibiotik } \\
\text { Antibiotics }\end{array}$} & \multicolumn{4}{|c|}{ Dosis (Dosage) } & \\
\hline & & 1 & 2 & 3 & 4 & \\
\hline \multirow{3}{*}{ Pantoea spp. } & Enrofloksasin & $35.3 \pm 0.6$ & $31.7 \pm 3.1$ & $21.3 \pm 2.5$ & $23.0 \pm 4.4$ & Rentan (Susceptible) \\
\hline & Eritrc & 9. & - & 11 & & Resisten (Resistant) \\
\hline & Oksitetrasiklin & $37.3 \pm 0.6$ & $32.7 \pm 0.6$ & $31.6 \pm 1.5$ & $26.7 \pm 0.6$ & Rentan (Susceptible) \\
\hline \multirow{3}{*}{ E. faecium } & Enrofloksasin & $28.7 \pm 3.5$ & $27.3 \pm 1.5$ & $17.3 \pm 6.5$ & $20.3 \pm 0.6$ & Rentan (Susceptible) \\
\hline & Eritromisin & - & - & - & - & Resisten (Resistant) \\
\hline & Oksitetrasiklin & $33.3 \pm 1.5$ & $27.0 \pm 3.0$ & $27.0 \pm 2.0$ & $25.3 \pm 1.5$ & Rentan (Susceptible) \\
\hline \multirow{3}{*}{ A. hydrophila } & Enrofloksasin & $39.3 \pm 4.5$ & $24.7 \pm 3.5$ & $25.3 \pm 3.5$ & $22.7 \pm 1.5$ & Rentan (Susceptible) \\
\hline & Eritromisin & $18.7 \pm 0.6$ & $12.7 \pm 1.5$ & $3.3 \pm 1.5$ & - & Resisten (Resistant) \\
\hline & Oksitetrasiklin & $35.3 \pm 2.5$ & $25.3 \pm 1.5$ & $24.7 \pm 2.5$ & $22.6 \pm 1.5$ & Rentan (Susceptible) \\
\hline
\end{tabular}

Keterangan (Note):

: tidak ada zona hambat (no zone of inhibition)
Dosis 1 (Dosage 1) : enrofloxacin $30,000 \mathrm{mg} / \mathrm{L}$; erythromycin $5,000 \mathrm{mg} / \mathrm{L} ;$ oxytetracycline $250,000 \mathrm{mg} / \mathrm{L}$
Dosis 2 (Dosage 2) : enrofloxacin $3,000 \mathrm{mg} / \mathrm{L}$; erythromycin $500 \mathrm{mg} / \mathrm{L} ;$ oxytetracycline $25,000 \mathrm{mg} / \mathrm{L}$
Dosis 3 (Dosage 3) : enrofloxacin $300 \mathrm{mg} / \mathrm{L} ;$ erythromycin $50 \mathrm{mg} / \mathrm{L} ;$ oxytetracycline $2,500 \mathrm{mg} / \mathrm{L}$
Dosis 4 (Dosage 4) : enrofloxacin $30 \mathrm{mg} / \mathrm{L}$; erythromycin $5 \mathrm{mg} / \mathrm{L}$; oxytetracycline $250 \mathrm{mg} / \mathrm{L}$

resisten. Terjadinya strain bakteri yang resisten terhadap antibiotik berpotensi menjadi strain virulen yang dapat memengaruhi sistem budidaya ikan (Cesare et al., 2012).

Bakteri C. freundii hasil isolasi dari ginjal ikan bidadari menunjukkan kerentanan (susceptible) terhadap ciprofloksasin dosis $5 \mathrm{mg}$, cefoxitin dosis $30 \mathrm{mg}$, dan tetrasiklin dosis $30 \mathrm{mg}$; akan tetapi, bakteri tersebut menunjukkan resistensi terhadap florfenikol dosis 30 $\mathrm{mg}$, oksitetrasiklin dosis $30 \mathrm{mg}$, ampisilin dosis 10 $\mathrm{mg}$, enrofloksasin dosis $5 \mathrm{mg}$, dan cefalotin dosis 30 mg (Gallani et al., 2016).

Isolat bakteri E. feacium dilaporkan sensitif terhadap ampisilin, penisilin, tetrasiklin dangentamisin), akan tetapi bakteri tersebut resisten terhadap rifampicin (Sarra et al., 2013). Wierzchowska et al. (2016) mengemukakan bahwa dari 35 isolat Enterococcus $\mathrm{sp}$. yang terisolasi, spesies yang dominan adalah $\mathrm{E}$. faecalis $(62,9 \%)$ dan $\mathrm{E}$. faecium $(28,6 \%)$. Isolat bakteri Enterococcus sp. tersebut $65,7 \%$ resisten terhadap setidaknya satu kelas antibiotik, dan 45,7\% diklasifikasikan sebagai resisten multi-obat. Persentase isolat yang resisten terhadap tetrasiklin adalah $48,6 \%$ resisten terhadap tigecycline dan fosfomycin $45,7 \%$

Menurut Kayis et al. (2009), dari 99 isolat bakteri ikan rainbow trout (Oncorhynchus mykiss) menunjukkan 26,26\%resisten dan 65,66\%rentan terhadap antibiotik oksitetrasiklin dosis $30 \mathrm{mg}$. Sedangkan sebanyak $52,04 \%$ bakteri resisten dan 10,20\% rentan terhadap antibiotik eritromisin $(15 \mathrm{mg})$.

\section{KESIMPULAN}

Bakteri yang terisolasi dari Ikan gabus (Channa striata) adalah Pasteurella pneumotropica dan Aeromonas hydrophila, pada ikan semah (Tor spp.) adalah Enterococcus faecium, Pantoea spp., dan Aeromonas hydrophila, sedangkan pada ikan baung (Hemibagrus sp.), Citrobacter freundii, dan Aeromonas hydrophila. Bakteri Enterococcus faecium, Pantoea sp., dan Aeromonas hydrophila memiliki tingkat virulensi yang rendah antara 3,3\%23,4\% sedangkan Citrobacter freundii dan Pasteurella pneumotropica tidak virulen terhadap ikan gabus, semah, dan baung. Bakteri Pantoea sp. dan A. hydrophila resisten terhadap antibiotik enrofloksasin dan eritromisin, sedangkan bakteri E. faecium resistens terhadap enrofloksasin, eritromisin, dan oksitetrasiklin.

\section{UCAPAN TERIMA KASIH}

Penelitian ini terlaksana dengan sumber dana dari DIPA BRPBATPP Tahun Anggaran 2018 komponen inovasi yang dihasilkan (2427.004.001.051.A) Kementerian Kelautan dan Perikanan dengan judul Sustainable Aquaculture: Budidaya Ikan Air Tawar Berkelanjutan. Penulis mengucapkan terima kasih kepada Dr. Tri Heru Prihadi, M.Si. sebagai penanggung 
jawab kegiatan, dan terima kasih kepada Bapak Setiadi, Edy Farid Wadjdy, Ahmad Wahyudi, dan Johan Afandi atas kerja sama dalam pelaksanaan kegiatan penelitian.

\section{DAFTAR ACUAN}

Al-Hisnawi, A.A., Mustafa, J.M., Yasser, Y.K., Hussain, K.A., \& Jabur, A.M. (2016). Influence of aquatic environment on microbiota of Liopropoma santi fish in a local river in Iraq. Karbala International Journal of Modern Science, XX, 1-5.

Alkhunni, S.B.A., Gaballah, M.S.M., \& Gultepe, N. (2017). Pathogenic bacteria for human and fish isolated from fish farm in Kastamonu, Turkey. Journal of Aquaculture \& Marine Biology, 6(3), 00157.

Apun, K., Yusof, A.M., \& Jugang, K. (1999). Distribution of bacteria in tropical freshwater fish and ponds. International Journal of Environmental Health Research, 9(4), 285-292.

Cesare, A.D., Vignaroli, C., Luna, G.M., Pasquaroli, S., \& Biavasco, F. (2012). Antibiotic-resistant enterococci in seawater and sediments from a coastal fish farm. Microbial Drug Resistance, 18(5). https://doi.org/10.1089/mdr.2011.0204.

Courtenay, W.R. \& Williams, J.D. (2004). Snakeheads (Pisces, Channidae) a biological synopsis and risk assessment. U.S. Geological Survey Circular 1251, $129 \mathrm{pp}$.

Farhana, A.A., Saad, C.R., Kamarudin, M.S., \& Daud, H.M. (2015). Growth performance and disease resistance towards Aeromonas hydrophila in Hemibagrus nemurus (Valenciennes, 1840) fingerlings through probiotic feeding. Iranian Journal of Fisheries Sciences, 14(4), 846-856.

Gallani, S.U., Sebastião, F.A., Valladão, G.M.R., Boaratti, A.Z., \& Pilarski, F. (2016). Pathogenesis of mixed infection by Spironucleus sp. and Citrobacter freundii in freshwater angelfish Pterophyllum scalare. Microbial Pathogenesis, 100, 119-123.

Igbinosa, E.O., Onuoha, T., \& Udochukwu, U. (2016). Antimicrobial resistance profile characterization of enterococcus species isolated from aquaculture environment. Journal of Microbiology \& Biotechnology, 1(2), 000107.

Kayis, S., Capkin, E., Balta, F., \& Altinok, I. (2009). Bacteria in rainbow trout (Oncorhynchus mykiss) in the Southern Black Sea Region of Turkey - A Survey. The Israeli Journal of Aquaculture - Bamidgeh, 61(4), 339-344.

Kluga, A., Kacaniová, M., Kantor, A., Kovalenko, K., \& Terentjeva, M. (2017). Identification of microflora of freshwater fish caught in the Driksna River and Pond in Latvia. FOODBALT, 16, 164-168.

Majewska, E.T. (2016). Improving disease prevention and treatment in controlled fish culture. Archives of Polish Fisheries, 24, 115-165.

Oztürk, R.C. \& Altýnok, I. (2014). Bacterial and viral fish diseases in Turkey. Turkish Journal of Fisheries and Aquatic Sciences, 14, 275-297.

Rakovac, R.C., Perinic, I.S., Popovic, N.T., Hacmanjek, M., Simpraga, B., \& Teskeredzic, E. (2002). Health status of wild and cultured sea bass in the northern Adriatic Sea. Veterinární medicína, 47(8), 222226.

Sarra, M., Taoufik, G., Patrick, L.C., Benjamin, B., Yannick, F., \& Khaled, H. (2013). Isolation and characterization of enterococci bacteriocinic strains from Tunisian fish viscera. Food and Nutrition Sciences, 4, 701-708.

Savasan, S., Kýrkan, S., Erbap, G., Parýn, U., \& Çiftci, A. (2016). The determination of virulence factors among fish originated enterococci. Etlik. Vet. Mikrobiyol Derg., 27(2), 98-103.

Svetlana, J., Dobrila, J.D., \& Veljoviæ, L.J. (2003). Citrobacter freundii as a cause of disease in fish. Acta Veterinaria, 53, 5-6. 10.2298/AVB0306399J.

Tendencia, E.A. (2004). Disk diffusion method. In Laboratory manual of standardized methods for antimicrobial sensitivity tests for bacteria isolated from aquatic animals and environment. Tigbauan, Iloilo, Philippines: Aquaculture Department, Southeast Asian Fisheries Development Center, p. 13-29.

Ture, M. \& Kutlu, I. (2018). Isolation of Citrobacter freundii from rainbow trout (Oncorhynchus mykiss) in freshwater cage. Journal of Limnology and Freshwater Fisheries Research, 4(2), 85-89.

Wierzchowska, W.C., Zadernowska, A., \& Trokenheim, L.L. (2016). Virulence factors, antimicrobial resistance and biofilm formation in Enterococcus spp. isolated from retail shrimps. Food Science and Technology, 69, 117-122. 